\title{
REFORM IN ASSESSMENT: TEACHERS' BELIEFS AND PRACTICES
}

\author{
Juliana Othman \\ University Malaya, Malaysia \\ E-Mail: juliana@um.edu.my
}

\begin{abstract}
Research has demonstrated that teachers' beliefs on teaching and learning plays a part on the way they teach and assess learning. A new assessment system for schools was implemented in 2011 to set the stage for change of the Malaysian education system from centralised examination to a combination of centralised examination and school-based assessment. There is a growing concern with implementation issues pertaining to how teachers will transform their assessment practices in their school contexts. Thus, this study sought to gain insights into teachers' beliefs about school based assessment, and examine the relationship between their beliefs and classroom practice. A survey measuring teachers' beliefs and practices of school based assessment was administered to 174 teachers who are currently educating in Malaysian government funded schools. Findings from this study demonstrated that teachers appear to have good knowledge of assessment principles about School Based Assessment (SBA). They conducted their assessment using appropriate procedures by considering the context of teaching and assessment in which they operate. The result of Pearson correlation analysis revealed a positive relationship between teachers' beliefs about SBA and their classroom practices.
\end{abstract}

Key words: teachers' beliefs, classroom practices, school based assessment

\section{INTRODUCTION}

School systems throughout the world are undergoing transformation from a fully central based assessment to partly school based assessment (Darling-Hammond and McCloskey, 2008; Fullan, 2011). It is believed that centralised summative examination is only partly useful and that it does not function as a help to student learning (Borich \& Tombari, 2004; Turnbull and Lash, 2013) and for that reason public school examination is changing into a combination of both school based assessment (SBA) and centralised examination.

In Malaysia for quite some time assessment has been formal and centralised. Realizing the importance of meaningful learning and the pressing need to produce excellent human experts equipped with problem solving and thinking skills rather than merely being good test takers, National Educational Assessment System (NEAS) was established by the Ministry of Education (MOE) to revise the existing curriculum and examination in 2011. Traditionally, examinations play a dominant role in the Malaysian educational system, primarily for the purpose of making high stake decisions. These decisions include the placement of learners who perform well academically in residential schools, provisions of scholarships, and even selection of graduates for better

Submitted April $6^{\text {th }}, 2018$, accepted for publication October $30^{\text {th }}, 2018$ 
employment opportunities (Ong, 2010). However, in light of the current educational assessment scenario, the National Educational Assessment System (NEAS) aims to enhance meaningful learning through School-Based Assessment (SBA) which focuses on assessment of learners' profiles, achievements, development and involvement.

The need for an assessment to be formative in nature has been recognised as important by the Ministry of Education. It is believed that the assessment is able to identify and remedy learning problems. The adoption of the formative assessment leads to introduction of different forms of assessments, including those of authentic alternative forms. This assessment for learning is used to obtain evidence whether learning has occurred so as to provide feedback to both teachers and students in order to formulate subsequent teaching and learning strategy (Wiliam \& Thompson, 2007). By employing this more holistic, balanced and sustainable assessment culture in teaching and learning, it is expected that SBA could complement the national examination where the results from the national examination will no longer be the sole yardstick for assessing learners' achievement.

SBA has been comprehensively implemented in various Western countries, as well as in Asia. Studies carried out in Hongkong, Singapore, South Africa and The United States, produced mixed results and encountered a variety of problems. In many studies such as those by Cromey \& Hanson (2000); Borich \& Tombari, 2004); Ye (2000) and Kimani, Kara \& Njagi (2013), factors of effectiveness of teacher training, teachers' beliefs, teachers' ability in preparing and implementing formative evaluation, school supports for SBA and availability of teaching-learning-assessment facilities, were found to be affecting teachers' as well as students' performance.

In Malaysia, SBA was initially implemented in all primary schools for all subjects including English, starting with lower primary schools in the same year. In this new assessment system, teachers are engaged at various levels of the assessment cycles from planning to final evaluation. Teachers are expected to be able to adopt the new educational reform and implement it into their classroom practices accordingly. The implementation of a new assessment system would require a change in teachers' beliefs and active engagement of the new assessment practices. It may also challenge certain beliefs that teachers hold with regards to the nature and purpose of evaluation.This major transformation in Malaysian educational system appears to place new demands on the teachers in grasping new assessment practices to produce learners who are independent thinkers (Mohd Yusof, 2013), since exam-dominated culture has been deeply rooted in Malaysian education system. It is widely reported that curriculum reform may cause uneasiness among teachers if the proposed change challenged their beliefs. Thus, it is essential to find out if the reform on Malaysian assessment system has an influence on teachers' assessment beliefs and their classroom practices. 


\section{LITERATURE REVIEW}

Various studies have examined teachers' beliefs with regard to different dimensions of the curriculum and how these beliefs were linked to their instructional practices. A great deal of previous research into teachers' cognition has suggested that teachers' beliefs influence their classroom practices (Basturkmen, 2012; Borg, 2003; Pajares, 1992). Findings from such research have indicated how teachers' beliefs influence their decision making that underlie their instructional practices (Davison, 2004; Yin, 2010: Neeson, 2000; Buyukkarci, 2014; James \& Pedder, 2006).

One area of research that has gained interest among the educators was the correspondence between teachers' assessment beliefs and their practices (Buyukkraci, 2014; Yin, 2010; Rea-Dickins, 2007). Chan's (2008) study examined EFL teachers' beliefs and multiple assessment practices at 520 elementary school in Taiwan. This study reported positive correlation between teachers' beliefs and their assessment practices. Similarly, a research on teachers in Hong Kong by Brown et. al (2009) revealed that assessment practices correspond with teachers' beliefs with regards to the purpose of assessment. In another study by Brown et. al (2015) in India, positive correspondence between teachers' assessment beliefs and their practices was also reported.

Several studies have reported that context played a mediating effect on the link between teachers' assessment beliefs and practices. Davison (2004) argued that one of the factors which influence teachers' assessment practices was their concern regarding how they will be evaluated by others on their classroom practices. In addition, Neeson (2000) and Shim (2009) studies revealed that contextual factors such as assessment training received, workload, support from administration and accountability to stakeholders also influenced teachers' classroom assessment practices. Despite of several studies linking teachers' beliefs to their teaching practices which offers evidence to support the relation (Chan, 2008; Brown et al, 2015; Davison, 2004; Shim, 2009), an equal number suggest inconsistency between beliefs and assessment practices (Chew and Lee, 2013; James \& Pedder, 2006; Yue, 2012).

In light of the revisions made to SBA over the years, there is an emergent awareness among the local educational researchers in several aspects of SBA in Malaysia lately. Studies on the implementation of SBA were conducted to assess its effectiveness and to identify problems involved in order to provide measures to improve the teaching and learning process so that learning could be enhanced. Among the major issues that are highlighted by the empirical studies in Malaysian context, are teachers' perceptions towards SBA (Malakonthu \& Hoon, 2010), teachers' concerns in the SBA implementation (Faizah, 2011), teachers' knowledge in the implementation of SBA (Gopala Krishnan, et. al, 2014), and the impact of SBA on instruction effectiveness (Mohd Aisamuddin \& Rohaya, 2013). In Salmiah Jaba (2013) study, it was found that teachers' acceptance of SBA is related with teachers' beliefs, attitudes and willingness to implement the assessment and also includes a change in educational values. However, very few studies (Rahim, Venville \& Chapman, 2009) have delved into the link between teachers' beliefs and their classroom assessment practices. Since SBA has been implemented for more than six years, it seems timely to examine how much progress teachers have made in implementing the assessment. 
The overall purpose of the study is to determine the interrelationships between teachers' beliefs and their school-based assessment practices. Through understanding teachers' assessment beliefs and practices, we could identify possible belief-practice gaps which inhibit the implementation of school based assessment. With this information, suitable recommendations can be made to improve current assessment practices.

Hence, the objectives for which this study attempts to achieve are as follows:

1. To examine the core belief teachers have on school-based asssessment.

2. To ascertain the extent to which the teachers' beliefs are consistent with their practices of school-based assessment.

\section{METHOD}

This study employed a quantitative design approach in obtaining information with regards to teachers' beliefs about school based asessment and the relationship with their classroom practices. A sample of 174 English language teachers were randomly sampled from secondary schools from five states in the Peninsular Malaysia. Of the total of 174 participants, $129(74.1 \%)$ were female and only $45(25.9 \%)$ were male. Teachers' ages ranged from below 30 to above 50. In this context the sample showed a balanced representation. In terms of teaching experience, the majority had been teaching for more than 3 years. In fact, the bulk of them had more than 11 years of teaching experience. The academic qualifications of the teachers in the sample range from teachers' certificates to masters degree. The spread mainly between teachers' certificates and bachelors' degrees really reflected the reality on the ground. Since it was felt that types of school might have effects on teachers' practices on SBA and the teachers were sampled from different schools, it is worthwhile to examine the types of school that these sampled teachers were derived from. In the sample, out of 174 teachers, 154 were from the government schools, 13 from government aided schools, and 7 from private schools.

\subsection{Instrument}

This study employed a survey, comprised of a questionnaire administered to 174 school teachers from five states in Malaysia. Respondents were asked to complete a validated questionnaire adapted from Shim's (2009) study. The questionnaire items were designed to elicit responses about teachers' beliefs and school based assessment practices. As Brown (2001) points out, psychological constructs such as beliefs or conceptions cannot be observed directly. Thus, the use of survey allows researchers to measure these constructs. The instrument comprised two sections: a) demographic and background information of respondents; b) items on teachers' beliefs about assessment and their instructional practices. A reliability analysis yielded a Cronbach's of .84 for the questionnaire items.

Part A asks teachers to respond to statements regarding their beliefs on SBA, while Part B consisted of items concerning teachers' assessment practices. The items are divided into four aspects of SBA procedures: planning, implementation, monitoring, recording and dissemination. The respondents indicate their responses based on a 5 point Likert scale (from $1=$ Never to $5=$ Very Often) to statements regarding assessment. Next, the survey responses from 174 teachers were statistically described and analysed. 


\section{FINDINGS}

Data analysis are first presented in relation to RQ1: What core beliefs do teachers have on school based assessment? The results of their responses on each statement are presented in Table 1, 2, 3, $4 \& 5$. Results pertaining to research question two are presented in Table 6 and 7.

\subsection{Teachers assessment beliefs}

This part of the questionnaire examined teachers' beliefs with regard to the planning stage of their formative assessment. Table 1 showed that majority of the repondents $73.5 \%(\mathrm{~m}=3.87)$ considered their students needs when they construct the assessment. Next, $67.3 \%(\mathrm{~m}=3.76)$ reported that they use assessment specifications when carrying out the assessment. Finally, 66.1\% $(\mathrm{m}=3.78)$ believed that assessment (tasks) are meaningful to the students. The data seems to show that the teachers are quite aware of the principles of SBA and its functions. They primarily plan their assessment by considering their students' needs against the curriculum specifications.

Table 1 Descriptive statistics of teachers' beliefs (Planning)

\begin{tabular}{|l|r|r|r|r|r|r|r|}
\hline Items & Mean & \multicolumn{1}{|l|}{$\begin{array}{l}\text { Std } \\
\text { Itev }\end{array}$} & \multicolumn{5}{|c|}{ Frequency \% } \\
\cline { 4 - 9 } & & & 1 & 2 & 3 & 4 & 5 \\
\hline 1. Consider the students' needs & 3.87 & 0.69 & 0 & 2.3 & 24.1 & 58.0 & 15.5 \\
\hline $\begin{array}{l}\text { 2. Assessment are meaningful } \\
\text { to the students }\end{array}$ & 3.78 & 0.74 & 0 & 3.4 & 30.5 & 50.6 & 15.5 \\
\hline $\begin{array}{l}\text { 3. Refer to assessment } \\
\text { specifications }\end{array}$ & 3.76 & 0.71 & 0 & 3.4 & 29.3 & 55.2 & 12.1 \\
\hline $\begin{array}{l}\text { 4. Students are provided with } \\
\text { similar learning } \\
\text { opportunities. }\end{array}$ & 3.76 & 0.72 & 0 & 3.4 & 30.5 & 52.9 & 13.2 \\
\hline $\begin{array}{l}\text { 5. Match performance targets } \\
\text { with students' needs. }\end{array}$ & 3.72 & 0.73 & 0 & 4.6 & 30.5 & 53.4 & 11.5 \\
\hline $\begin{array}{l}\text { 6. Identify the purpose of } \\
\text { assessment. }\end{array}$ & 3.71 & 0.76 & 0.6 & 4.0 & 31.0 & 52.9 & 11.5 \\
\hline
\end{tabular}

In terms of teachers' beliefs in implementing SBA, the results in Table 2 revealed that $67.1 \%(\mathrm{~m}=3.74)$ of the teachers claimed that they would provide the students with explicit instructions on how to do the assessment tasks. In addition, 60.3\% $(\mathrm{m}=3.70)$ teachers reported that support to students would be given when they have problem in completing assessment tasks. Next, 59.7\% $(\mathrm{m}=3.64)$ of the teachers said that they believe in giving the students an opportunity to monitor their progress while completing the assessment. Lastly, 57.4\% $(\mathrm{m}=3.59)$ of the respondents said that they believe in giving immediate feedback to the students after they complete each assessment. In sum, the teachers' beliefs are generally in line with the principles of formative assessment which promote students' learning. 
Table 2 Descriptive statistics of teachers' beliefs (Implementation)

\begin{tabular}{|c|c|c|c|c|c|c|c|}
\hline \multirow[t]{2}{*}{ Items } & \multirow[t]{2}{*}{ Mean } & \multirow{2}{*}{$\begin{array}{l}\text { Std } \\
\text { Dev }\end{array}$} & \multicolumn{5}{|c|}{ Frequency $\%$} \\
\hline & & & 1 & 2 & 3 & 4 & 5 \\
\hline $\begin{array}{l}\text { 1. Provide explicit instruction to } \\
\text { students on how to carry out the } \\
\text { assessment (tasks). }\end{array}$ & 3.74 & 0.70 & 0 & 3.4 & 30.5 & 55.2 & 10.9 \\
\hline $\begin{array}{l}\text { 2. Students are supported when they } \\
\text { face problems in completing the } \\
\text { assessment (tasks). }\end{array}$ & 3.70 & 0.68 & 0 & 1.7 & 37.9 & 49.4 & 10.9 \\
\hline $\begin{array}{l}\text { 3. Students are given opportunity to } \\
\text { monitor their own performance while } \\
\text { carrying out the assessment (tasks). }\end{array}$ & 3.64 & 0.71 & 0 & 4.6 & 35.6 & 51.1 & 8.6 \\
\hline $\begin{array}{l}\text { 4. Inform the students of the reasons } \\
\text { why they are being assessed. }\end{array}$ & 3.62 & 0.82 & 1.1 & 5.2 & 37.9 & 42.5 & 13.2 \\
\hline $\begin{array}{l}\text { 5. Students are given immediate } \\
\text { feedback after completing each } \\
\text { assessment (task). }\end{array}$ & 3.59 & 0.67 & 0 & 3.4 & 41.4 & 48.3 & 6.9 \\
\hline
\end{tabular}

As for monitoring the assessment, majority of the teachers, i.e. $71.8 \%(\mathrm{~m}=3.86)$ indicated that assessments were used as part of their classroom teaching, as shown in Table 3. Moreover, $68.9 \% \quad(m=3.83)$ of the teachers reported that the results of assessment were used to improve their teaching, and $60.9 \%(\mathrm{~m}=3.68)$ believed that the scoring criteria must be related to the goals of the assessment. As a whole, the findings seemed to indicate that these teachers viewed assessment as an essential tool in providing them with information so as to make informed pedagogical decisions. This result corresponds with the principles of SBA which stated that feedback from classroom asssessment could be utilised to improve instructional process.

Table 3 Descriptive statistics of teachers' beliefs (Monitoring)

\begin{tabular}{|c|c|c|c|c|c|c|c|}
\hline \multirow[t]{2}{*}{ Items } & \multirow[t]{2}{*}{ Mean } & \multirow{2}{*}{$\begin{array}{l}\text { Std } \\
\text { Dev }\end{array}$} & \multicolumn{5}{|c|}{ Frequency $\%$} \\
\hline & & & 1 & 2 & 3 & 4 & 5 \\
\hline $\begin{array}{l}\text { 1. Assessments are made as part } \\
\text { of teaching and learning. }\end{array}$ & 3.86 & 0.67 & 0 & 1.1 & 27.0 & 56.3 & 15.5 \\
\hline $\begin{array}{l}\text { 2. Assessment feedbacks are used } \\
\text { positively. }\end{array}$ & 3.83 & 0.70 & 0 & 1.1 & 30.5 & 52.3 & 16.1 \\
\hline $\begin{array}{l}\text { 3. Assessment feedbacks are used } \\
\text { as input for their teaching. }\end{array}$ & 3.83 & 0.70 & 0 & 1.7 & 29.3 & 53.4 & 15.5 \\
\hline $\begin{array}{l}\text { 4. Mark the students' } \\
\text { performance consistently. }\end{array}$ & 3.71 & 0.70 & 0 & 4.0 & 30.5 & 55.7 & 9.8 \\
\hline $\begin{array}{l}\text { 5. Scoring criteria are in line with } \\
\text { the goals of the assessment. }\end{array}$ & 3.68 & 0.72 & 0 & 4.0 & 35.1 & 50.0 & 10.9 \\
\hline
\end{tabular}

Scale: 1=Never $2=$ Hardly ever $3=$ Sometimes $\quad 4=$ Quite often $5=$ Very often 
In terms of recording and disseminating assessment results, Table 4 displayed that $77.6 \%(\mathrm{~m}=3.98)$ of the teachers believed that they are responsibile for the output of their professional work $(\mathrm{m}=3.98)$. Total of $69.6 \%(\mathrm{~m}=3.85)$ believed students' right as assessment takers must be assured, and $64.4 \%$ agreed that report on students' progress and achievement should be given. In sum, teachers were concerned with assessment serving the goals of accountability.

Table 4 Descriptive statistics of teachers' beliefs (Recording \& Dissemination)

\begin{tabular}{|l|l|l|l|l|l|c|c|}
\hline Items & Mean & \multicolumn{1}{|c|}{$\begin{array}{l}\text { Std } \\
\text { Dev }\end{array}$} & & \multicolumn{5}{|c|}{ Frequency \% } \\
\cline { 4 - 9 } & & & 1 & 2 & 3 & 4 & 5 \\
\hline $\begin{array}{c}\text { 1. Responsible for the output } \\
\text { of their professional work. }\end{array}$ & 3.98 & 0.72 & 0 & 2.3 & 20.1 & 55.2 & 22.4 \\
\hline $\begin{array}{c}\text { 2. Believed in students' rights } \\
\text { as assessment takers. }\end{array}$ & 3.85 & 0.71 & 0 & 1.7 & 28.7 & 52.9 & 16.7 \\
\hline $\begin{array}{l}\text { 3. Provide reports about the } \\
\text { students' progress and } \\
\text { achievement. }\end{array}$ & 3.74 & 0.74 & 0 & 4.0 & 31.6 & 50.6 & 13.8 \\
\hline
\end{tabular}

Scale: $1=$ Never $\quad 2=$ Hardly ever $3=$ Sometimes $\quad 4=$ Quite often $\quad 5=$ Very often

Findings on teachers' classroom practices as shown in Table 5 indicated that $56.3 \%$ $(\mathrm{m}=3.55)$ of the teachers reported that they used feedback on their students performance to improve their teaching, 55.7\% $(\mathrm{m}=3.51)$ stated that they put more emphasis on fostering the development of students all around skills, $54.6 \%(\mathrm{~m}=3.51)$ claimed that they teach students according to the SBA requirement. These results seem to suggest that teachers implement assessment principles which they believed are important in enhancing their learners' performance. By identifying students' strengths and weaknesses, teachers believed that they could take remedial actions.

Table 5 Descriptive statistics of teachers' classroom practices

\begin{tabular}{|l|c|c|c|c|c|c|c|}
\hline Items & Mean & \multicolumn{1}{|c|}{$\begin{array}{l}\text { Std } \\
\text { Dev }\end{array}$} & & \multicolumn{6}{|c|}{ Frequency \% } \\
\cline { 4 - 8 } & & & 1 & 2 & 3 & 4 & 5 \\
\hline $\begin{array}{l}\text { 1. Provide more opportunities for my } \\
\text { students to interact during class. }\end{array}$ & 3.61 & 0.75 & 0 & 6.3 & 36.2 & 47.7 & 9.8 \\
\hline $\begin{array}{l}\text { 2. Use feedback on my students' } \\
\text { SBA performance to improve } \\
\text { my teaching. }\end{array}$ & 3.55 & 0.81 & 0.6 & 9.2 & 33.9 & 47.1 & 9.2 \\
\hline $\begin{array}{l}\text { 3. Am motivated to share my } \\
\text { teaching material/ ideas with } \\
\text { other teachers. }\end{array}$ & 3.55 & 0.74 & 0 & 7.5 & 37.9 & 47.1 & 7.5 \\
\hline $\begin{array}{l}\text { 4. Put more emphasis on giving my } \\
\text { students feedback. }\end{array}$ & 3.53 & 0.72 & 0 & 7.5 & 37.9 & 48.9 & 5.7 \\
\hline $\begin{array}{l}\text { 5. Teach my students according to } \\
\text { the SBA requirement. }\end{array}$ & 3.51 & 0.74 & 0 & 9.2 & 36.2 & 49.4 & 5.2 \\
\hline
\end{tabular}

Scale: $1=$ Never 2=Hardly ever $3=$ Sometimes $4=$ Quite Often $5=$ Very Often 


\subsubsection{Beliefs and their assessment practices.}

In Table 6, the correlation between teachers' assessment beliefs and practices is displayed. The Pearson's correlation result showed that there is a significant and positive relationship $(\mathrm{r}=0.541, \mathrm{p}<0.01)$ between teachers' beliefs and assessment practices. This finding implies that teachers are more likely to implement school-based assessment in their classroom practices if they hold strong beliefs of the assessment principles.

Table 6 Correlation between teachers' SBA beliefs and practices.

\begin{tabular}{|l|c|c|}
\hline & Teacher's beliefs of SBA & Teachers' practices of SBA \\
\hline Teachers' beliefs of SBA & 1 & $.541 * *$ \\
Teachers' practices of SBA & $.541 * *$ & 1 \\
\hline \multicolumn{2}{|c}{$* * \mathrm{p}<0.01$} &
\end{tabular}

A One-Way ANOVA was computed to test the relationship between teachers' teaching experiences, beliefs and practices. The result from the analysis shown in Table 7 indicated no significant difference $[\mathrm{F}(3,170)=0.490, \mathrm{p}=0.69]$ of the relationship between teachers' beliefs and their years of teaching experience. However, it is interesting to note that the results on the relationship between teaching experience and teachers' practices yielded a statistically significant difference $[F$ 93, 170 $)=5.849$, $\mathrm{p}=0.001]$.

Table 7 ANOVAS of teaching experiences and beliefs \& practices

\begin{tabular}{|l|l|l|l|l|l|l|}
\hline Types & & Sum of Sqs & df & Mean sq & F & Sig. \\
\hline Beliefs & Between grps & 22.187 & 3 & 7.396 & .490 & .690 \\
& Within grps & 2566.054 & 170 & 15.094 & & \\
& Total & 2588.241 & 173 & & & \\
\hline Practices & Between grps & 267.583 & 3 & 89.194 & 5.849 & $.001^{*}$ \\
& Within grps & 2592.578 & 170 & 15.250 & & \\
& Total & 2860.160 & 173 & & & \\
\hline
\end{tabular}

\section{DISCUSSION AND CONCLUSION}

There are various factors involved in planning and implementation of SBA ranging from those of cultural, demographic, political, technological, to those of the dynamics of teaching and learning in the classroom. However, the interplays of all these variables are hardly understood. Apart from examining the factors involved in the management of SBA both at school level as well as at classroom levels, it is noted that teachers' beliefs did play an important role in the success of any change, particularly with regards to curriculum. As Brown (2008) points out, studies on teachers' assessment beliefs are motivated by the view that beliefs affect practices.

This study attempts to examine teachers' beliefs and practices in Malaysian schools context. In terms of the four aspects of school-based asessment processes, i.e. planning, 
implementing, monitoring and reporting, the study found that the teachers indicated strong beliefs towards the school-based assessment principles. The results from the statistical analyses showed that the teachers in this study believed in the importance of giving feedback, considering students needs, the use of meaningful task in their classrooms and that asessment should facilitate their students' learning process. In gauging the status of teachers' beliefs in performing the required tasks in SBA, it was found that these teachers were almost well prepared in all the measures. The Pearson correlation analysis yielded a significant relationship between teachers' beliefs and their assessment practices. These findings concur with other studies (Brown et. al, 2015; Buyukkarci, 2014; Chan, 2008; Davison, 2004; Yin, 2010), indicating the correspondence between teachers' beliefs and classroom assessment practices.

One of the reasons for this outcome could be due to the effectiveness in the training and other given support provided after the Ministry had managed to get the feedbacks from the teachers (Norzila Mohd Yusof, 2013). The cascade training strategy introduced earlier, for example, was replaced with face to face exposure and close monitoring strategy. IT facilities were quickly improved when it was found that at the earlier stage the online services in particular posed quite an obstacle in keeping students' records. Evidence from the findings seemed to reveal that SBA as a new system of teaching, learning, and assessing, has a teething problem at the initial stage but that it can be improved. The teachers in Malaysia can be said to be much open to accept change provided that the shift does not incur over burdening as shown by studies such as that of Abdul Zubir (2007).

The findings of this study also found that teachers' status in terms of their teaching experiences related quite significantly to their teaching practices. These findings concur to the earlier findings in which years of teaching experience had bearings on the ability to perform in teaching and learning included in SBA (Kimani, Kara \& Njagi, 2013 and Ye, 2000). Based on this evidence, policy makers would be able to plan for teachers' selection for a more effective way of implementing SBA.

The main implication that can be drawn from this study is that changes in educational policy should only be implemented after necessary preparations are in place. In order to implement an educational reform effectively, sufficient training on the new reform must be conducted for different stakeholders. Moreover, teachers should be given support and opportunities to participate in continuous professional development programs so as to increase their level of competency in school-based assessment. They also need to be encouraged to carry out reflections and self-assessment in order to develop awareness of their own beliefs and practices.

Lastly, there is a limitation to this study which relied solely on a questionnaire to elicit stated beliefs and self-reported practices of the respondents. Further research by means of qualitative research method involving interviews, observations and document analysis would be essential to establish the implementation of these beliefs so as to gain better understanding of the link between teachers' assessment beliefs and instructional practices. 


\section{REFERENCES}

Abdul Zubir, "Pelaksanaan Pentaksiran Berasaskan Sekolah Dikalangan Guru Tingkatan Tiga"

Phd diss, University Malaya, 2007.

Basturkmen, H. (2012). Review of research into the correspondence between language teachers' stated beliefs and practices. System, 40, 282- 295. http://dx.doi.org/10.1016/j.system.2012.05.001

Brown, J.D. (2001). Using Surveys in Language Programs. Cambridge: Cambridge University Press.

Brown, G.T.L. (2008). Conceptions of assessment: Understanding what assessmnet means to teachers and students. New York, NY: Nova Science Publishers.

Brown, G. T. L., Kennedy, K. J., Fok, P. K., Chan, J. K. S., \& Yu, W. M. (2009). Assessment for student improvement: Understanding Hong Kong teachers' conceptions and practices of assessment. Assessment in Education: Principles, Policy \& Practice, 16 (3), pp. 347-363. https://doi.org/10.1080/09695940903319737

Brown, G.T.L., Chaudry, H., \& Dharmija, R. (2015). The impact of an assessment policy upon teachers' self-reported assessment beliefs and practices: A quasi-experimental study of Indian teachers in private schools. International Journal of Educational Research, 71, pp. 50-64.

Borg, S. (2003) Teacher cognition in language teaching: A review of research on what language teachers think, know, believe, and do. Language Teaching, 36(2). Pp. 81109. https://doi.org/10.1017/S0261444803001903

Borich, G., \&Tombari, M. (2004). Educational assessment for the elementary and middle school classroom. New Jersey: Pearson, Merill Prentice Hall.

Buyukkarci,K. (2014). Assessment Beliefs and Practices of Language Teachers in Primary Education. International Journal of Instruction, 7(1), pp. 107-118.

Chan, Y. C. (2008). Elementary school EFL teachers' beliefs and practices of multiple assessments. Reflections on English Language Teaching, 7(1), pp. 37-62.

Chew, A. and Lee, I. (2013). Teachers' beliefs and practices of classroom assessment in Republic Polytechnic, Singapore 39th Annual Conference of the International Association of Educational Assessment (IAEA),Tel Aviv, Israel.

Cromey, A., \& Hanson, M. (2000). An exploratory analysis of school-based student assessment systems. North Central Regional Educational Laboratory: Learning Point Associates.

Darling-Hammond, L. and L.McCloskey, (2008). Assessment for learning around the world. What would it mean to be internationally competitive? Phi Delta Kappa, 90(4):263-272.

Davison, C. (2004). The contradictory culture of classroom-based assessment: Teacher assessment practices in senior secondary English. Language Testing, 21(3), pp. 305334. https://doi.org/10.1191/0265532204lt286oa

Faizah Majid. (2011). School-based assessment in Malaysian schools: The concerns of English teachers. Journal of US-China Education Review, 8 (10), pp. 1-15. 
Fullan, M. (2011). Choosing the wrong drivers for whole system reform. Seminar Series Paper No. 204, Centre for Strategic Education.

Gopala Krishnan, S.N., Roszainora, S., Nor Zaitolakma, A. S., Raja Nurul Huda R.Z, Azyanee, L., Thenmolli, V. \& Haslina, C.N. (2014). Teachers' knowledge and issues in the implementation of school-based assessment: A case of schools in Terengganu. Asian Social Science, 10 (3), pp. 186-194.

James, M., \& Pedder, D. (2006). Beyond method: assessment and learning practices and values. The Curriculum Journal, 17 (2), 109-138. https://doi.org/10.1080/ 09585170600792712

Kimani, G. N. Kara, A. M. \& Njagi, L. W. (2013). Teacher factors influencing students' academic achievement in secondary schools in Nyandarua County, Kenya. International Journal of Education and Research, 1 (3), pp. 1-14.

Malakolunthu, S. \& Hoon, S.K (2010). Teacher perspectives of school-based assessment in a secondary school in Kuala Lumpur. World Conference on Learning, Teaching and Administration Papers. Procedia Social and Behavioral Sciences, 9 , pp. 1170-1176.

Mohd Aisamuddin Mat Hassan \& Rohaya Talib. (2013). Perceptions towards SBA implementation among teachers in Malaysian schools. Paper presented in the Seminar on Quality and Affordable Education, Johor Bahru, Malaysia.

Mohd Yusof, N. (2013). School-based Assessment: Transformation in Educational Assessment in Malaysia. Examination Syndicate, Ministry of Education Malaysia. Paper presented at the Cambridge Horizons Seminar on School-based Assessment: Prospects and Realities in Asian Contexts.

Neesom, A. (2000). Report on teachers' perception of formative assessment QCA's Assessment for Learning Project. London: Qualification and Curriculum Authority.

Ong, S. L. (2010). Assessment profile in Malaysia: High-stakes external examinations dominate. Assessment in Education: Principles, Policy \& Practice, 17 (1), 91-103.

https://doi.org/10.1080/09695940903319752

Pajares, M. F. (1992). Teachers' beliefs and educational research: Cleaning up a messy construct. Review of Educational Research, 62 (3), pp. 307-332

Rahim, S. S. A., Venville, G., \& Chapman, A. (2009). Classroom assessment: Juxtaposing teachers' beliefs with classroom practices. 2009 Australian Association for Research in Education: International Education Research Conference.

Rea-Dickins, P. (2007). 'Learning or measuring? Exploring teacher decision-making in planning for classroom-based assessment' in Form-focused Instruction and Teacher Education: Studies in Honour of Rod Ellis. Oxford: Oxford University Press, pp. 193-210.

Salmiah Jaba, Ramlah Hamzah, Abdul Rahim Bakar \& Abdullah Mat Rashid. (2013). Acceptance towards school based assessment among agricultural integrated living skills teachers: Challenges in implementing a holistic assessment. Journal of Technical Education and Training, 5(1), pp. 44-51.

Shim, K.N. "An Investigation into Teachers' Perceptions of Classroom-Based Assessment of English as a Foreign Language in Korean Primary Education". PhD thesis, University of Exeter, 2009).

Turnbull, E. and Lash, A. (2013). Understanding Formative Assessment: Insights from Learning Theory and Measurement Theory https://www.wested.org/online_pubs/resource1307.pdf 
Wiliam, D. \& Thompson, M. "Integrating assessment with instruction: what will it take to make it work?" In The future of assessment: shaping teaching and learning edited by C. A. Dwyer, p. 53-82, Mahwah, NJ: Lawrence Erlbaum Associates, 2007.

Ye, R. "The effects of teacher characteristics, beliefs, relations with students, and inservice education on student science achievement." Phd diss., Texas Tech University, 2000.

Yue, L.S. "Primary school teachers' beliefs and practices of classroom assessment". Masters in Education diss., Nanyang Technological University, National Institute of Education, 2012.

Yin, M. (2010). Understanding Classroom Language Assessment through Teacher Thinking Research. Language Assessment Quarterly. 7 (2), p. 20. 